\section{Energy intake, body image, physical activity and nutritional status of teenagers}

\author{
Ratna Candra Dewi, ${ }^{1,2}$ \\ Bambang Wirjatmadi ${ }^{2}$
}

${ }^{1}$ Sport Science Faculty, Universitas

Negeri Surabaya; ${ }^{2}$ Faculty of Public

Health, Universitas Airlangga, Indonesia

\begin{abstract}
The physical appearance of an individual is important for teenagers. An assessment known as "body image," is a feeling of satisfaction or dissatisfaction with the state of the body and its appearance. The study aimed to analyze body image, energy adequacy, physical activity, and nutritional status. A total of 95 students of Sport Science at the State University of Surabaya were examined in this research using observational analytic and a cross sectional study design. Anthropometric measurements include evaluating body weight and height, examining the consumption pattern data using the $2 \times 24$ hour recall method and food frequency questionnaire. Furthermore, it analyzes the physical activity using the International Physical Activity Questionnaire method, and determines body image using questionnaires. Energy adequacy is calculated by comparing the average energy consumption with Recommended Dietary Allowances, while the nutritional status is measured using the Body Mass Index. Similarly, the relationships between variables were analyzed using the Spearman Rank Correlation Test. The results showed that there was a significant relationship between energy intake, adequacy, body image, and nutritional status.
\end{abstract}

\section{Introduction}

Adolescence is a transition period within the lifespan of all humans, which is marked by major physical, emotional and psychological changes. The criteria possessed by adolescents are inseparable from the values or social norms that exist. Each individual has an ideal self-image of what they require including body shape. Mismatch between the body shape and perceived by an individual leads to dissatisfaction. Body image is a mental representation of the shape and size of the human body, which is influenced by biological, historical, sociocultural and individual factors. Its individual level of satisfaction is depicted by the overall acceptable physical appearance. The deep gap between the body perceived by the individual and the ideal body leads to a negative assessment.

The greater the discrepancy, the lower the assessment achieved. However, people with positive assessment make adequate use of their bodies. There are many consequences related to negative body image for instance, teenagers try to maintain their appearance by regulating their eating habits, but ignoring nutritional and health rules which influences their eating behavior. ${ }^{1}$ Furthermore, they start to eat fewer calories to avoid being obesed or overweight. Conversely, an unhealthy lifestyle and also a lack of awareness of health leads majority of them into eating excessively, which leads to obesity. ${ }^{2}$

\section{Materials and Methods \\ Research design and samples}

This research is an observational analytic with cross sectional study design. The sample consists of 95 male students of Sports Science at the State University of Surabaya selected using the simple random sampling technique.

\section{Data collection and measurement}

Data measurement included anthropometry which is used to determine the weight and height, consumption pattern with $2 \times 24$ hour recall method and food frequency questionnaire. Furthermore, physical activities were collected using the IPAQ (International Physical Activity Questionnaire) method, while body image was taken using a questionnaire. The level of energy adequacy was calculated by comparing the average energy consumed with Recommended Dietary Allowances. Nutritional status was measured using the Body Mass Index (BMI) with the formula weight $(\mathrm{kg}) /$ height $(\mathrm{m})^{2}$.

\section{Data analysis}

Spearman Rank Correlation Test was used to analyze the relationships between variables by SPSS version 22.0.

\section{Results}

The results showed participants characteristics and the relationship between the explanatory variables and nutritional status (Tables 1 and 2).

Table 1 shows participants food consumption rate which is an average of
Correspondence: Ratna Candra Dewi, Doctoral Program of Public Health, Faculty of Public Health, Universitas Airlangga, Jl. Mulyorejo, Surabaya, Jawa Timur 60115, Indonesia.

Tel.: +62.31.5920948 - Fax: +62.31.5924618

E-mail: ratnadewi@unesa.ac.id

Key words: energy intake, body image, physical activity, nutritional status.

Acknowledgments: The authors are grateful to all the teenagers and data collectors who volunteered and participated in this study.

Contributions: the authors contributed equally.

Conflict of interest: the authors declare no potential conflict of interest.

Funding: none

Clinical trials: the study is not involved any clinical trials.

Conference presentation: part of this paper was presented at the $3^{\text {rd }}$ International Symposium of Public Health, 2018 October 31 - November 1, Universitas Airlangga, Surabaya, Indonesia.

Dedication: the article is dedicated to Doctoral Program of Public Health, Faculty of Public Health, Universitas Airlangga, Surabaya, Indonesia; Universitas Negeri Surabaya, Surabaya, Indonesia.

Received for publication: 28 July 2019.

Revision received: 9 September 2019.

Accepted for publication: 15 October 2019.

This work is licensed under a Creative Commons Attribution NonCommercial 4.0 License (CC BY-NC 4.0).

(C) Copyright: the Author(s), 2019

Licensee PAGEPress, Italy

Journal of Public Health in Africa 2019; 10(s1):1194 doi:10.4081/jphia.2019.1194

$2780.53 \pm 278.42 \mathrm{kcal}$ with an energy adequacy level of $84.21 \%$. Most participants had physical activity in the moderate category $(63.16 \%)$, positive body image $(74.74 \%)$, and normal nutritional status $(89.47 \%)$

Table 2 shows a significant relationship $(<0.05)$ and positive values between energy intake, adequacy, body image and physical activity with nutritional status.

\section{Discussion}

Teenagers develops a sense of 
independence and identity, while at the same time they develop more reasoning skills and a stronger sense of being self, they define their own identities, good and bad self-image or body image. Health care professionals should be aware of implementing teenagers' assessment as an evaluation of teenagers' health status. ${ }^{3}$ The awareness of body image among adolescents is very strong, especially in those experiencing puberty. At this stage, they experience hormonal changes physically, sexually and emotionally. Physical changes are the most easily seen by teens and other people. ${ }^{4}$

Presently, personal physical images are a means to gain access to various places in a real or virtual social environment. Efforts are made by both men and women to maintain their body appearance through the use of cosmetics products, piercings and tattoos, plastic surgery, sports materials and equipment, etc. When growing up, children build pictures of themselves, which tends to develop through things around them. Poor assessments of our body causes low selfesteem and reduce self-confidence. However, media plays an important role in building positive body image of teenagers. Research shows that eating disorders contributes to building an ideal body image which in most cases results to anorexia nervosa or bulimia, the use of steroids, protein supplements and plastic surgery.

\section{Body image}

Body image represents a psychological construct with cognitive, behavioral and perceptual dimensions, including attitudes toward the body itself and image which includes multidimensional structures that represent feelings, thoughts and behaviors. ${ }^{5,6}$ The development of body image is a lifelong process. ${ }^{7}$ Rapid physical changes that occur along with maturity in puberty have important effects on body image. Factors that influence its development in adolescents include rapid growth and development, sexual maturity, and formation of identity. ${ }^{8}$ During this period, teens develop a picture of what is seen on their bodies, with anxiety. ${ }^{9}$

It is influenced by family, friends and culture, as no one is born with a negative body image. Children's experiences are shaped by different messages in the society. ${ }^{10}$ Positive or negative information during childhood and adolescence also affects adults. ${ }^{11}$ Furthermore, socio-cultural factors that involve peers and media influence such as ethnicity, social status, culture, family, school conditions, norms and peer pressure will also shape the body image. ${ }^{12}$ However, the most influential are family, peers and the media. ${ }^{13}$ Social learning and first life experiences are very important, such as the role of the family, interactions between peers, the effects of the media and negative experiences such as bullying. ${ }^{14}$

Many studies focus on the body image of women who desire to be thinner and while ignoring men. ${ }^{15}$ However others ${ }^{16,17}$ have stated that men also have body image problems. This research indicates that men may differ from women in their perceptions of overall body composition, shape and specific attention to other areas. ${ }^{15,18}$ Men itch for muscles especially in regions above the waist, while majority of women want to lose fat from the waist down such as the hips, thighs and buttocks. ${ }^{19}$

Cristiana $^{20}$ study showed a significant correlation between body image perception and self-esteem, mediated by weight and fat deposits. The results indicated that there is a statistically significant correlation between body mass index (BMI) and dissatisfaction $(\mathrm{r}(158)=0.56, \mathrm{p}<0.0005)$, with a $79 \%$ prevalence in young women. Approximately, $87.7 \%$ of subjects had a normal and thin BMI category, while majority $(66 \%)$ wanted to lose weight. There is a significant negative correlation between body image dissatisfaction and self-esteem as the higher the dissatisfaction, the lower the self-esteem. This is illustrated with $\mathrm{r}$ $(158)=0.56, p<0.0005$ and a significant correlation between perceptions of health and self-esteem ( $\mathrm{r}=0.36 ; \mathrm{p}<0.005)$. Integrating Physical and Health Education in strategies to prevent overweight will have an effect in reducing the occurrence of physical and emotional disorders. ${ }^{21}$

\section{Physical activity}

Physical activity includes all involves all kinds of body movements such as play, work, active transportation, homework, sports, and recreational activities. Formal physical activity is a planned, structured, repetitive, and aims to improve or maintain one or more components of physical fitness, create a balance between energy intake and expenditure. Physical activity is one way to improve health during adolescence and its amount is dependent not only on gender, but also on body image. Teenage boys with negative body images will be less physically active. The challenge in health promotion is to maintain a relatively good perception of their body image while promoting physical activity. Prevention programs must target the promotion of a healthy lifestyle for all teenagers, both women and men.

Physical activity and exercise con-

Table 1. Variables of the participant's characteristics.

\begin{tabular}{llcc} 
Variables & Category & Amount & Percentage (\%) \\
Energy Intake & $2000-2499 \mathrm{kcal}$ & 12 & 12.63 \\
& $2500-2999 \mathrm{kcal}$ & 63 & 66.32 \\
& $3000-3499 \mathrm{kcal}$ & 20 & 21.05 \\
& Minimum: & 2200 & \\
& Maximum: & 3350 & \\
& Mean: & 2780.53 & \\
& SD: & 278.42 & \\
Energy Adequacy & Good & 80 & 84.21 \\
& Poor & 15 & 15.79 \\
\hline Body Image & Positive & 71 & 74.74 \\
& Negative & 24 & 25.26 \\
Physical Activity & Minutes $(<600$ MET-minutes a day) & 23 & 24.21 \\
& Moderate (600 - < 1500 MET-minutes a day) & 60 & 63.16 \\
& High (1500 - <3000 MET-minutes a day) & 12 & 12.63 \\
\hline Nutritional Status & Underweight (BMI $\leq 18.4)$ & 8 & 8.42 \\
& Normal (BMI $18.5-25)$ & 85 & 89.47 \\
& Overweight (BMI $\geq 25.1)$ & 2 & 2.11 \\
\hline
\end{tabular}

MET: Metabolic equivalents; BMI: Body Mass Index.

Table 2. The relationship between the explanatory variables and nutritional status.

\begin{tabular}{lcc} 
Variables & Correlation Coefficient ( $\mathrm{r}$ ) & Sig. \\
Energy Intake & 0.432 & 0.000 \\
Energy Adequacy & 0.276 & 0.007 \\
\hline Body Image & 0.203 & 0.048 \\
Physical Activity & -0.096 & 0.355 \\
\hline
\end{tabular}


tribute between $25 \%$ and $50 \%$ of total daily energy expenditure and this is an important factor for weight control. There is evidence that active individuals, who are overweight/obese, possess a healthier mass and body composition compared to the inactive ones. The internet has taken a big part of our time, keeping us sitting and staring at the screen for a long time, with changes in communication, learning, and behavior patterns. Its exposure has shaped how to search and obtain information, learn and interact socially. In a short time, no one will be required to memorize information anymore, as everything will be accessible in one click. People, who work, shop, pay taxes and entertain themselves online, will spend less time on transportation and have fewer interpersonal interactions. However, owing to its addiction, people are likely to experience setbacks in imagination, memory, sharpness, sedentary lifestyle, indoor life without sunlight and fresh air, consume unhealthy food, underdeveloped lungs, with the limited possibilities of physical abilities.

Physical activity is basically important for maintaining the function of life because it has been shown to have a protective role in the development of cardiovascular diseases, metabolic and skeletal disorders, as well as mental illness. Regular physical exercise will be beneficial to health. Practical interventions and scientific studies show potential positive effects for exercise and will improve physical and psychological well-being. Scientific evidence shows that exercise is positively related to changes in body image.

\section{Factors related to nutritional status}

Healthy lifestyles, good nutrition and physical activity prevent various cardiometabolic diseases, hypertension, cancer, obesity and other related ailments. ${ }^{24} \mathrm{~A}$ healthy lifestyle among adolescents and young adults is associated with a number of psychosocial and behavioral protective and risk factors which increases the likelihood of involvement in risky behavior. Protective factors reduce the possibility of involvement in risky behavior by providing a positive model of social behavior, through social and individual supervision and control, and a supportive environment. Risk and protective factors exist in all social systems and individuals. ${ }^{25}$ The importance of knowledge and practice of healthy lifestyles during growth is an essential way to prevent high cases of obesity. Healthy behavior needs to be emphasized at the early stages of life. ${ }^{26}$ Individuals tend to further their education at the end of adolescence and early adulthood. However, various activities during college potentially lead to eating disorders. ${ }^{27}$ Some of these include physiological and psychological factors such as changes in identity and role, lack of physical activity, cafeteria food, and availability as well as ease of buying junk food. ${ }^{27,28}$ Healthy behaviors are formed during higher education which may have a long impact on health promotion and disease prevention. ${ }^{29}$

Male students are less concerned with weight and adopt fewer strategies compared to women. Female students have been shown to have healthier habits related to alcohol consumption, nutrition and less stress, while men show higher rates of overweight and are less interested in nutritional advice or healthy activities. ${ }^{30}$

\section{Conclusions}

There is a significant relationship between energy intake, adequacy level, body image, and nutritional status.

\section{References}

1. Widianti N, Candra A. Hubungan antara body image dan perilaku makan dengan status gizi remaja putri di SMA Theresiana Semarang (Relationship between body image and eating behavior with nutritional status young women at Teresia High School Semarang). J. Nutr. Coll. 2012;1:398404.

2. Arisman. Buku ajar ilmu gizi dalam daur kehidupan (Nutrition science textbooks in the life cycle). Jakarta: EGC; 2010.

3. Cash TF. Cognitive-Behavioral Perspectives on Body Image. Encyclopedia of Body Image and Human Appearance 2012;1:187-193.

4. Santrock JW. Adolescence (15th Edition). New York: McGraw-Hill Education; 2014.

5. Thompson JK, Heinberg JK. The Media's Influences on Body Image Disturbance and Eating Disorders: We've Reviled Them, Now Can We Rehabilitate Them? Journal of Social Issues 1999;55(2):339-353.

6. Muth JL, Cash TF. Body-image attitudes: What difference does gender make? Journal of Applied Social Psychology 1997;27(16):1438-1452.

7. Tantleff-Dunn S, Gokee JL. Interpersonel influences on body image development. In T. F. Cash, \& T. Pruzinsky (Eds.), Body image: A handbook of theory, research and clinical practice (pp.108-116). New
York: The Guilford Press; 2002.

8. Levine MP, Smolak L. Body image development in adolescence. In T. F. Cash, \& T. Pruzinsky (Eds.), Body image: A handbook of theory, research and clinical practice (pp.74-82). New York: The Guilford Press; 2002.

9. Wright MRV. Body image satisfaction in adolescent girls and boys: A longitudinal study. Journal of Youth and Adolescence 1989;18:71-83.

10. Davis B. What"s real, what"s ideal: Overcoming a negative body image . New York: The Rosen Publishing Group, Inc.; 1999.

11. Sarwer DB, Wadden TA, Pertschuk MJ, et al. The psychology of cosmetic surgery: A review and reconceptulization. Clinical Psychology Review 1998;18(1):1-22.

12. Smolak L. Body image development in children. In T. F. Cash, \& T. Pruzinsky (Eds.), Body image: A handbook of theory, research and clinical practice (pp.65-73). New York: The Guilford Press; 2002.

13. Abrams LS, Stormer CC. Sociocultural variations in the body image perceptions of urban adolescent females. Journal of Youth and Adolescence 2002;3:443-450.

14. Neziroğlu F, Khemlani-Patel S, Veale D. Social learning theory and cognitive behavioral models of body dysmorphic disorder. Body Image 2008;5:28-38.

15. Andersen A, Cohn L, Holbrook T. Making weight: Men's conflicts with food, weight, shape, and appearance. Carlsbad, CA: Gurze Books; 2000.

16. Drewnowski A, Yee DK. Men and body image: Are males satisfied with their body weight? Psychosomatic Medicine 1987;49:626-634.

17. Mishkind ME, Rodin J, Silberstein LR, et al. The embodiment of masculinity: Cultural, psychological, and behavioral dimensions. American Behavioral Scientist 1986;29:545-562.

18. Cohane GH, Pope HG. Body image in boys: A review of the literature. International Journal of Eating Disorders 2001;29:373-379.

19. McCabe MP, Ricciardelli LA. Body image and body change techniques among young adolescent boys. European Eating Disorders Review 2001;9:335-347.

20. Pop CL. Physical Activity, Body Image, and Subjective Well-Being. Well-being and Quality of Life-Medical Perspective 2017. Available from: http://dx.doi.org/10.5772/intechopen.68 333. Accessed on: 10 May 2018.

21. Diener E, Scollon C, Lucas R. The 
envolving concept of subjective wellbeing: The multifaceted nature of happines. Advances in Cell Aging and Gerontology 2003;15:187-219.

22. Peper E, Lin I-M. Increase or decrease depression: How vody postures influence your energy level. Biofeedback 2012;40(3):125-130.

23. Scutti S. Change Your Posture To Improve Your Mood, Memory, and 5 Other Aspects of Your Live; 2014. Available from: http://www.medicaldaily.com/changeyour-posture-improve-your-moodmemory-and-5-other-aspects-your-life289724. Accessed on: 10 May 2018.

24. Mokdad AH, Marks JS, Stroup DF, et al. Actual causes of death in the United
States. JAMA 2005;291:1238-1245.

25. Jessor R, Turbin MS, Costa MF. Predicting developmental changes in healthy eating and regular exercise among adolescent in China and the United States: The rule of psychosocial and behavioral protection and risk. Journal of Research on Adolescence 2010;1-19.

26. World Health Organization. Obesity: preventing and managing the global epidemic. Report of a WHO consultation. Geneva, Switzerland: World Health Organization; 2000.

27. Compas BE, Wagner BM, Slavin LA, et al. A prospective study of life events, social support, and psychological symptomatology during the transition from high school to college. Am J Commun Psychol 1986;14:241-57.

28. Levitsky DA, Halbmaier CA, Mrdjenovic G. The freshman weight gain: A model for the study of the epidemic of obesity. Int J Obes Relat Metab Disord 2004;28(11):1435-42.

29. Mareno N. Wellness characteristics and health risk behaviors of young adult university students. Dissertation Abstracts International: Section B: The Sciences and Engineering 70(7B):4089; 2010.

30. Cluskey M, Grobe D. College weight gain and behavior transitions: Male and female differences. J Am Diet Assoc 2009;109(2):325-9. 